\title{
Unique Features and Applications of Chlorine Dioxide on Disinfection
}

\author{
Chunhong Ta \\ Jilin Jianzhu University \\ Changchun, China \\ tachunqi@126.com
}

\begin{abstract}
Disinfection is an important measure to ensure the water quality security. Chlorine dioxide -as a strong oxidizer is widely used for disinfection of drinking water and wastewater. This paper firstly introduces the basic properties of chlorine dioxide, then detailly analyses its disinfection -functionality and advantages, finally discuss the prospect of application
\end{abstract}

Keywords-Chlorine dioxide; Chlorine dioxide Disinfection; Disinfectant

\section{INTRODUCTION}

The distribution of water resources spatial and temporal heterogeneity, rapid population increase, expansion of production capacity, urbanization, low water resource utilization-, extravagant habits of water etc cause the serious shortage of water resources ${ }^{[1,2,3]}$., which not only -severely restricts the economic development, but also causes infaust psychological -influnence ${ }^{[4]}$-on the residents, even may lead to significant social and political crisis.Therefore, on the basis of saving water, it is imminent to develop the unconventional water sources from many aspects in order to address a series of serious problems caused by the shortage of water resources Compared with newly developed sources of water, wastewater reuse is an effective way of low cost, quick solution to the problem of water shortage. How to choose a highly effective disinfectant with the low cost and less disinfection by-products has become the focus of attention. Chlorine dioxide is a high chemical activity and strong oxidant, and produces less environmental pollution. Now the application of chlorine dioxide has been broadened widely, especially in sterilization.

\section{A. Properties of chlorine dioxide disinfectant}

Chlorine dioxide when disinfection is generally exists in solution form, it's usually gas is yellow, in the solution concentration was $14 \sim 17 \mathrm{mg} / \mathrm{L}$ odor, achieved when $45 \mathrm{mg} / \mathrm{L}$ is irritating. Chlorine dioxide gas can be compressed into a liquid at room temperature, density is $2.4 \mathrm{~kg} / \mathrm{L}$, the boiling point of $11 \mathrm{DEG} \mathrm{C}$, melting point $59{ }^{\circ} \mathrm{C}$. When chlorine dioxide is exposed to light or in contact with organic material with the temperature rise will explode. In industry, chlorine dioxide transport through a mixture of air, to keep the concentration of chlorine dioxide in $8 \% \sim 12 \%$. In the dark, chlorine dioxide solution can be stored for several months.

The solubility of $\mathrm{ClO}_{2}$ is 5 times larger than the $\mathrm{Cl}_{2}$, redox potential is 1.15 times higher than $\mathrm{Cl}_{2}$, but not as easy as chlorine with water or ammonia reacts with the ${ }^{[5]}$. Because the $\mathrm{ClO}_{2}$ does not with water, NH3 and chloramine,therefore does not break point such as chlorine dosage and residual volume curve formed by ${ }^{[6]}$. Moreover, $\mathrm{ClO}_{2}$ has obvious volatile, as long as the removal of ${ }^{[5]}$ from water by simple aeration. In addition, $\mathrm{ClO}_{2}$ exists in the resonance structure of $\mathrm{AB} 2$, the electronic structure of the $\mathrm{ClO}_{2}$ molecule was not saturated, but in the water but not to two poly or poly state exists, this is good for $\mathrm{ClO}_{2}{ }^{[6]}$ in the rapid diffusion of water.

\section{B. General technical characteristics of 2 chlorine dioxide disinfection}

In recent years, domestic and foreign scholars have studied the exploration and validation of chlorine dioxide disinfection effect, many test results show that the application of chlorine dioxide disinfection with chlorine disinfection in water treatment practice has more ideal effect.

\section{Effectively kill bacteria propagule.}

Ridenour (1947) study demonstrated that, in $\mathrm{pH} 7$ water, not to $0.1 \mathrm{mg} / \mathrm{L}$ doses of chlorine dioxide in $5 \mathrm{~min}$ can kill typhoid, paratyphoid, dysentery bacillus, Escherichia coli bacteria and other common enteric bacteria; in the range of pH6 10, its bactericidal effect is not affected. Benarde (1965) proved by the experiment, when $\mathrm{pH}>8.5$, the disinfection effect of chlorine dioxide chlorine 20 times faster than ${ }^{[7]}$.

In recent years, through research on the disinfection effect of chlorine dioxide, results show that under certain conditions of chlorine dioxide on Staphylococcus aureus and Escherichia coli bacteria in $1 \sim 2 \mathrm{~min}$, the killing rate is more than $99.9 \%{ }^{[8]}$.On the role of Escherichia coli $2 \mathrm{~min}$, killing rate up to $99.99 \%$, if the action of $10 \mathrm{~min}$, it can be completely kill. To make a long story short, chlorine dioxide is very powerful to kill bacteria propagule.

\section{D. effectively kill virus}

Is generally believed that the effect of chlorine dioxide on virus is stronger than the chlorine or similar. As early as in 1946, there were reports, chlorine dioxide with inactivated polio virus (Polio virus) role, its effect is similar with free chlorine. Other researchers also reported in the $\mathrm{pH}$ than neutral or the presence of ammonia, chlorine dioxide in the inactivation of F2 phage, Ke Saqi virus B3, ECHO virus, vaccinia virus, phage phi X174, Sendai virus Andvaccine virus than chlorine strong.

Aieta $5 \mathrm{mg} / \mathrm{L}$ of chlorine dioxide and chlorine in the two grade in the sewage treatment of Escherichia coli bacteriophage phi 8 and Polio virus I virus killing effect. 
The results showed that chlorine dioxide, inactivation of phage phi 8 and Polio virus I than $\mathrm{Cl}$ intensity. Longley has the similar reports, they compared the chlorine and chlorine dioxide in waste water of phage killing effect, the dosage of $5 \mathrm{mg} / \mathrm{L}$, contact time, 3min, chlorine inactivation of $1 \mathrm{log}$ level, and chlorine dioxide inactivated phage reached $3 \log { }^{9]}$ and above.

\section{E. Effective in killing bacterial spores}

As the chlorine dioxide has strong oxidation, so it on the spores of bacteria also has a strong bactericidal effect.Compare it with the same concentration of chlorine, and concluded that chlorine dioxide sporicidal effect is stronger than chloride. Experimental conclusion, it to be anthrax spore inactivation ability is 5 times stronger than chlorine. A study of chlorine dioxide with a $15 \mathrm{~min}$ concentration of $1000 \mathrm{mg} / \mathrm{L}$, the spores of Bacillus subtilis var.niger killing rate of up to $100 \%{ }^{[10]}$.

\section{F. Kill fungus}

Chlorine dioxide effect of $5 \mathrm{~min} 500 \mathrm{mg} / \mathrm{L} 100 \%$, can kill to Trichophyton; but the role of $200 \mathrm{mg} / \mathrm{L} 60 \mathrm{~min}$, of Aspergillus fumigatus by calf serum protection $0.03 \%$ of the killing rate reached 99.9999\%; 100mg/L 60 seconds,with $0.03 \%$ calf serum protection of Candida albicans in the killing rate was 99.99999\%. Be11 Research Report2min, chlorine dioxide, the acrylic resin with $10 \%$ horse serum protection of Candida albicans killing rate reached $100 \%{ }^{[11]}$. There are reports containing $4.5 \sim$ compound disinfectant of chlorine dioxide and chlorine $5.0 \mathrm{mg} / \mathrm{L}$ available chlorine for Candida albicans of $1 \sim 2 \mathrm{~min}$, the killing rate is more than $99.9 \%$.

\section{G. .Effectively kill algae and plankton}

Tests show, killing effect of chlorine dioxide on filamentous algae, Chlorella, ankistrodesmus, prismatic desmids, Cladophora algae increases with the concentration of the disinfectant, and basically is better than or equal to the liquid chlorine.

In $\mathrm{pH}=7.0$, to kill 20min, experiments show that with the increase of the amount of disinfectant, killing of protozoan and metazoan more. Liquid chlorine dosage increases to $7.0 \mathrm{mg} / \mathrm{L}$, all protozoa and metazoa were killed, and the chlorine dioxide to achieve the same result is only $5.0 \mathrm{mg} / \mathrm{L}$.

\section{H. Remove part of organic matter}

Chlorine dioxide oxidation ability is very strong, has good removing effect on phenolic compounds in water, but also on the polycyclic aromatic hydrocarbons, nitrosamines, griseofulvin, aflatoxin and mustard gas and other mutagens and carcinogens oxidation degradation product has good removal capability. According to reports in the literature,chlorine dioxide can be carcinogenic BaP oxidized quinone, non carcinogenic, when water is added $8.4 \mathrm{mg} / \mathrm{L}$ $\mathrm{ClO} 2$,the $\mathrm{BaP}$ removal rate can reach $80 \%$, which is the chlorine disinfection is not up to ${ }^{[6]}$. In addition, the ability of chlorine dioxide caused by the removal of organic matter in water color taste is also very strong, water can be 2, 3,6- 2- three chlorobenzene ether, methyl isoborneol, 2- isopropyl 3- methoxy pyrazine and 2- isobutyl -3- methoxypyrazine and odor removal. These compounds in water even PPT level will also have great taste.

\section{DISINFECTION CHARACTERISTIC OF DISINFECTANT}

Some researchers the disinfection effect of chlorine dioxide and chlorine were compared, as shown in table 1. Can be seen that under the same conditions, disinfection effect of chlorine dioxide is obviously better than that of chlorine; to achieve the same effect, shorter contact time of chlorine dioxide disinfectant required dosage less ${ }^{[13]}$

TABLE I. COMPARISON OF CHLORINE DIOXIDE AND CHLORINE DISINFECTION

\begin{tabular}{|c|c|c|c|}
\hline $\begin{array}{c}\text { Disinfection } \\
\text { Effect }\end{array}$ & $\begin{array}{l}\text { Chlorine dioxide } \\
\text { disinfection } \\
\text { (concentration } \\
\text { and action time) } \\
\text { dioxide } \\
\text { disinfection }\end{array}$ & $\begin{array}{c}\text { Chlorine } \\
\text { disinfection } \\
\text { (concentration } \\
\text { and action time) }\end{array}$ & document \\
\hline $\begin{array}{l}\text { One of the water } \\
\text { source of Shanghai } \\
\text { city Minhang } \\
\text { bacteria in raw } \\
\text { water reached } 100 \% \\
\text { of the inactivation }\end{array}$ & $\begin{array}{l}2.5 \mathrm{mg} / \mathrm{L}, \\
15 \mathrm{~min}\end{array}$ & $\begin{array}{l}3.0 \mathrm{mg} / \mathrm{L} \text {, } \\
60 \mathrm{~min}\end{array}$ & $\begin{array}{r}\text { Mo } \\
\text { Xingkang, } \\
2000[14]\end{array}$ \\
\hline $\begin{array}{l}\text { On E.coli } \\
\text { inactivation rate } \\
\text { reached } 99 \%\end{array}$ & $\begin{array}{l}1.4 \mathrm{mg} / \mathrm{L}, \\
20 \mathrm{~min}\end{array}$ & $\begin{array}{l}1.8 \mathrm{mg} / \mathrm{L}, \\
20 \mathrm{~min}\end{array}$ & \multirow{3}{*}{$\begin{array}{l}\text { Huan } \\
\text { g Junli, } \\
\text { 2002[6] }\end{array}$} \\
\hline $\begin{array}{l}\text { Staphylococcus } \\
\text { aureus reached } \\
98 \% \text { of the } \\
\text { inactivation rate }\end{array}$ & $\begin{array}{l}2.5 \mathrm{mg} / \mathrm{L}, \\
2 \mathrm{~min}\end{array}$ & $\begin{array}{l}2.5 \mathrm{mg} / \mathrm{L} \text {, } \\
3.5 \mathrm{~min}\end{array}$ & \\
\hline $\begin{array}{l}\text { The prismatic } \\
\text { desmids reached } \\
\text { 85\% and the killing } \\
\text { rate Engineering }\end{array}$ & $\begin{array}{l}4 \mathrm{mg} / \mathrm{L}, \\
30 \mathrm{~min}\end{array}$ & $\begin{array}{l}5 \mathrm{mg} / \mathrm{L}, \\
30 \mathrm{~min}\end{array}$ & \\
\hline $\begin{array}{c}\text { The } \\
\text { Cryptosporidium } \\
\text { oocysts inactivation } \\
\text { rate reached } \\
\text { 90\%Management }\end{array}$ & $\begin{array}{l}\text { 1.3ppm, } \\
60 \mathrm{~min}\end{array}$ & $\begin{array}{l}\text { 80ppm, } \\
\text { 90min }\end{array}$ & $\begin{array}{c}\text { Koric } \\
\text { h et al, } \\
1990[12]\end{array}$ \\
\hline
\end{tabular}

\section{III.SUMMARY AND OUTLOOK}

Due to the high-effective and broad-spectrum bactericidal effect of chlorine dioxide, it works long lasting,and its diffusion speed in water and penetration ability are faster than chlorine, especially in low concentrations exhibiting the more obvious effect. In addition, using chlorine dioxide as a disinfectant, there is almost no disinfection by-products to form , and the process is rarely affected by $\mathrm{pH}$ value and organism . It has been widely used in the drinking water.

Moreover, the long-term practice also proved that chlorine dioxide is the most ideal chemical disinfectant in the present. There are more extensive applications in the catering, food, medical, aquaculture industry disinfection ${ }^{[17]}$. 


\section{REFERENCES}

[1] Zhou Tong. Decision making and technologv for wastewater reuse. Beijing: Chemical Industry Press, 2002

[2] Oian vi. Sewage resources is an effective wav to solve the water crisis. Beijing planning and construction,1996, (4): 5-7

[3] USEPA.Guidelines for water reuse. EPAA/625/R92/004. US Environmental Protection Agencv. Center forEnvironmental Research Information, Cincinnati, Ohio, 1992

[4] Zhou Tong. The effective wav is to solve the sewage with citv water. Water supply and drainage, 2001b, 27(11): 1-6

[5] Wanvan Hua. A Kshin. Chen Jiandong. The pronerties of chlorine dioxide and its apblication in water treatment. Railwav occunational safetv. health and environmental protection, 1994,21 (3): 220

[6] Huang Junli. New tvne of water treatment agent -chlorine dioxide technologv and application. Beijing: Chemical Industry Press, 2002,5

[7] Gu Chunving. Xue Guangbo. Progress of research on chlorine dioxide disinfection. Shanghai Journal of preventive medicine, 1999,11 (11): 496

[8] Shi Laishun. Xie Zhaoren. The effect of comnound chlorine dioxide disinfectant test on the killing effect ofmicroorganisms in the water. Journal of China disinfection science, 1996,13 (1): 30

[9] Chen Guoaing. Chlorine dioxide inactivated viruses in water. The neonle's Liberation Army preventive medicine, 1994,12 (6): 499
[10] [Ju Xiiuan Test renort the disinfection effect of chlorine dioxide disinfectant stabilitv. See: Huang Zhiming.Apolication Manual of stable chlorine dioxide. Shanghai: Science Press, 1993

[11] Bell J.A.. Brockmann S.L.. Feil-P. et al. The effectiveness of two disinfectants on denture base acrvlic resinwith an organic load. J Prosthet Dent, 1989, 61 (5): 580

[12] Korich D.G.. Mead J.R.. Madore M.S.. et al. Effects of ozone. chlorine dioxide. Chlo rine. and monochloramineon Crvntosnoridium narvum oocvst viability. Ap pl Environ Microbiol, 1990,56 (5): 1423

[13] Chen-Yu Chang. Yung-Hsu Hsieh. I-Chen Shih. ShenSheng Hsu. Kuo-Hua Wang.The formation and controlof disinfection bv-nroducts using chlorine dioxide. Chemosphere, 2000,41:1181-1186

[14] Mo Xingkang. Tang Linsheng Zhou Yun. Different raw water bv laboratorv studies of chlorine dioxide disinfection. Chemical standardization and quality supervision, 2000 (1): 13-17

[15] 「Wang Yongvi. Li Na. Studv on antimicrobial algicidal effect of chlorine dioxide. Industrial water treatment,1994,14 (6): 14

[16] Zhang Jinsong. Drinking water with chlorine dioxide nurification technology. Beijing: Chemical Industry Press,2002,12:181178

[17] Narkis N..Katz A..Orshanskv F..Kott Y..Friedland Y.. Disinfection of efficient bv combinations of chlorine dioxide and chlorine. Water Sci. Tech, 1995, 31(5):105-114. 